\title{
RELATIONSHIP BETWEEN A RANGE OF TISSUE TEMPERATURE AND LOCAL OXYGEN UPTAKE IN THE HUMAN FOREARM. II. CHANGES OBSERVED AFTER ARTERIAL OCCLUSION, IN THE PERIOD OF REACTIVE HYPEREMIA 1, 2
}

\author{
By DAVID I. ABRAMSON, ALAN KAHN, HABIB REJAL, GEORGE A. TURMAN, \\ SAMUEL TUCK, JR., AND CLARA J. FLEISCHER
}

\author{
(From the Departments of Physical Medicine and Rehabilitation and Medicine, University of \\ Illinois College of Medicine, Chicago, Ill.)
}

(Submitted for publication January 2, 1958; accepted March 27, 1958)

It is generally accepted that the magnitude of the hyperemic response which follows deprivation of local circulation is related to the metabolic needs of the involved tissues (1-3). However, as has already been pointed out (4), conclusions regarding oxygen consumption cannot be based on blood flow measurements alone.

In the present investigation, therefore, it was decided to study the excess oxygen uptake of the tissues of the forearm (exclusive of bone) after a period of arterial occlusion, using the Fick principle. Furthermore, it was considered of interest to determine whether or not an experimentally produced alteration in tissue temperature influenced the magnitude of the oxygen repayment during reactive hyperemia in the same manner as has been reported in the case of oxygen uptake of resting tissues (4).

\section{METHOD}

Twenty-seven experiments were performed on 23 healthy subjects between the ages of 18 and 52 years. Sixteen were males and seven were females. The duration of an experiment averaged six hours, during which time food intake was restricted to one or two small chocolate bars.

Utilizing the same techniques and environmental conditions described in the previous paper (4), the following measurements were made: blood flow, oxygen content of venous blood and muscle, ${ }^{3}$ subcutaneous tissue

\footnotetext{
1 This investigation was supported in part by Research Grant H-2568 from the National Institutes of Health, United States Public Health Service.

2 This paper was presented at the International Cardiovascular Society meeting at San Francisco, Calif., on June 21, 1958.

3 The muscle thermocouple was inserted perpendicularly to the skin into the upper portion of the forearm for an average distance of $4.2 \mathrm{~cm}$. (range of 3.0 to 6.0 $\mathrm{cm}$.).
}

and skin temperatures, all obtained from the upper twothirds of the forearm. The temperature of the water in the plethysmograph (bath temperature) was first maintained at $45^{\circ} \mathrm{C}$. and then lowered to $17^{\circ}$, and under each of these experimental conditions all of the above measurements were taken, together with blood pressure and pulse rate readings, obtained from the opposite limb, and determinations of rectal temperature. For reasons discussed below, attempts were made to cannulate a vein in the antecubital fossa which had no obvious superficial tributaries and which appeared to drain deep tissues primarily. However, as already pointed out (4), it was not always possible to achieve this aim.

Plan of experiment. After tissue temperature readings were obtained under resting conditions and with air in the plethysmograph (at an average temperature of $29.3^{\circ}$ C.), the machine was filled with water at a temperature of $45^{\circ} \mathrm{C}$. Following a period of more than 90 minutes of exposure of the forearm to the heat, control values for blood flow, venous oxygen content and tissue temperatures were collected. Then compressed air at an arterial pressure was permitted to enter the $6 \mathrm{~cm}$. wide pneumatic cuff on the arm (ordinarily used for the application of a collecting pressure in the production of a blood flow reading) and this level was maintained for five minutes.

Immediately after the sudden release of the arterial occlusion pressure on the arm, blood flow readings (Figure 1 ), venous blood samples and temperature recordings were obtained at rapid intervals, generally four to five of each being collected in the first minute of reactive hyperemia, two to three in the second, and four spaced over the next four to eight minutes. In every instance care was taken not to draw a blood sample at the same time that a blood flow was being recorded.4 It was felt that removal of blood from the segment of forearm in the plethysmograph during such a period might detract from the rate of enlargement of the limb produced by the venous collecting pressure and thus decrease the blood

\footnotetext{
4 Since the initial blood flow readings were obtained by applying a venous occlusion pressure for no more than three seconds, such a precaution offered no real difficulty in obtaining an adequate number of blood samples.
} 


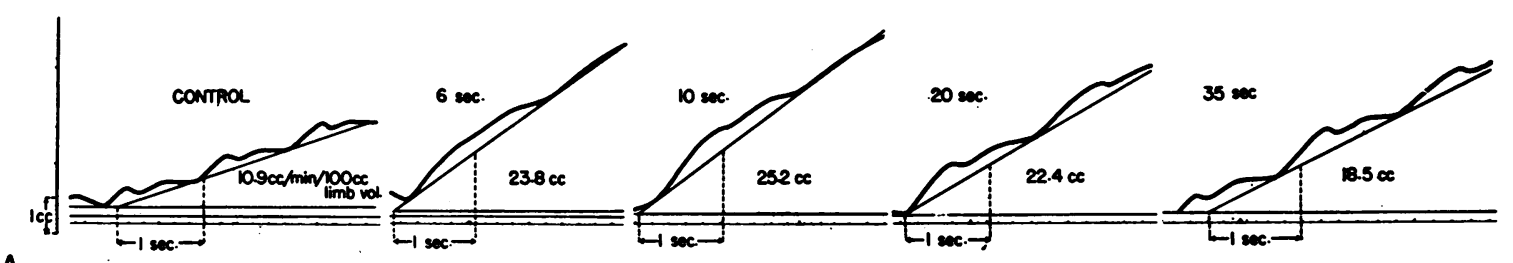

A
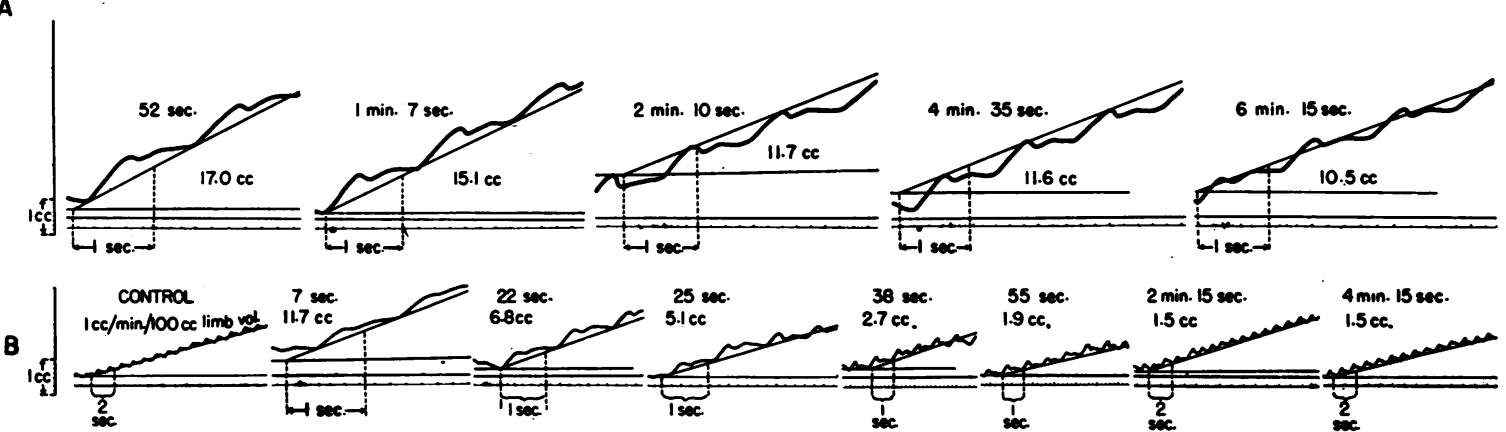

Fig. 1. Forearm Blood Flow Curves Obtained on Subject C. M. Before and After a Five Minute Period of Arterial Occlusion

$\mathrm{A}=$ control and postocclusion readings collected at a bath temperature of $45^{\circ} \mathrm{C} . \quad \mathrm{B}=$ control and postocclusion readings collected at a bath temperature of $17^{\circ} \mathrm{C}$. The calculated blood flow, in cc. per minute per $100 \mathrm{cc}$. limb volume, and the time in the period of reactive hyperemia are indicated for each determination. Calibration scale, in cc. divisions, is to the left of the curve. An arterial occlusion pressure was maintained at the wrist during blood flow recordings.

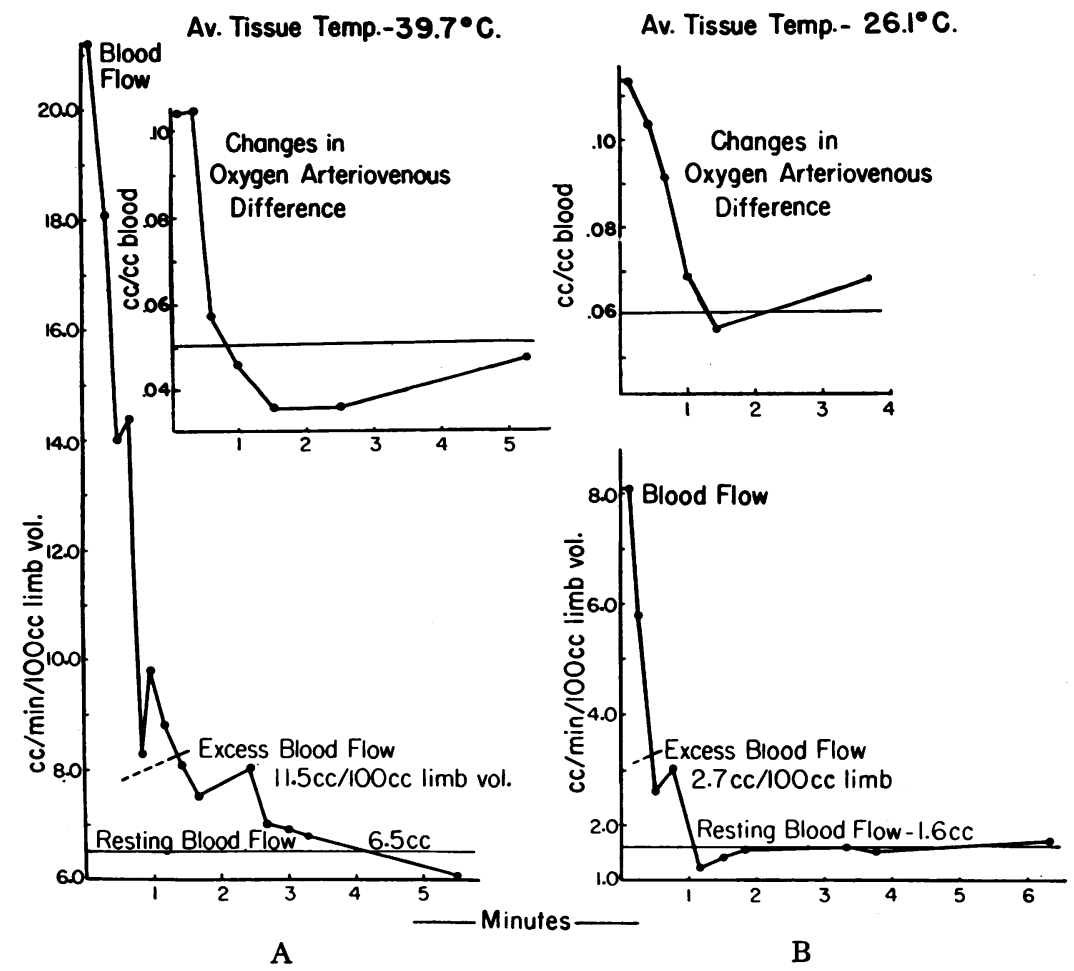

Fig. 2. Graphs of Blood Flow and Oxygen Arteriovenous Differences Obtained During Reactive Hyperemia on Subject J. S.

$\mathrm{A}=$ bath temperature of $45^{\circ} \mathrm{C} . \quad \mathrm{B}=$ bath temperature of $17^{\circ} \mathrm{C}$. 
flow reading. The possibility that the collecting pressure might raise the venous oxygen in the sample of blood was not seriously considered, for the period of application utilized early in reactive hyperemia was only approximately three seconds and, therefore, not long enough to have any effect (5).

Throughout the experiment the venous collecting pressure was $60 \mathrm{~mm}$. $\mathrm{Hg}$, despite the possible objection, recently expressed (6), that this level might be too high for the determination of the initial blood flow obtained four seconds after the onset of reactive hyperemia. With the method used for the application of the venous collecting pressure, there was a delay of more than one second in the build-up in the cuff to $60 \mathrm{~mm}$. $\mathrm{Hg}$, and, consequently, it was felt that the height of pressure initially was not great enough to interfere with arterial inflow. This view was supported by the results obtained in a group of six subjects in whom first a venous collecting pressure of $60 \mathrm{~mm}$. $\mathrm{Hg}$ was used and then, in another period, a pressure of $40 \mathrm{~mm}$. $\mathrm{Hg}$. Both under resting conditions and during reactive hyperemia at high and low bath temperatures, the blood flow readings were substantially the same for the two procedures, even early in the period of re-establishment of circulation.

After the various readings had returned to the preocclusion baseline, the bath temperature was lowered to $17^{\circ} \mathrm{C}$. and maintained at this level for approximately 90 minutes before control sets of readings were collected. When this was accomplished the arterial circulation was again occluded for five minutes. On release of the pressure data were collected at rapid intervals, as in the case of a bath temperature of $45^{\circ} \mathrm{C}$.

\section{RESULTS}

From the readings of blood flow and derived oxygen arteriovenous difference obtained at the two bath temperatures, oxygen uptake was calculated both for the resting state and for the period of reactive hyperemia, using the Fick principle (7). The predicted oxygen debt developed during the period of arterial occlusion was determined by multiplying the resting oxygen uptake by five minutes (the duration of application of the arterial occlusion pressure).

Three different graphs were constructed for each bath temperature, on the basis of changes in 1) blood flow, 2) oxygen arteriovenous difference, and 3) oxygen uptake, respectively, observed in the period of reactive hyperemia (Figures 2 to 5 ). In each instance the figures were plotted against time in minutes, while a baseline was derived generally by averaging three to five control readings collected before arterial occlusion with a similar number obtained after reactive hyperemia had subsided. In the case of the blood

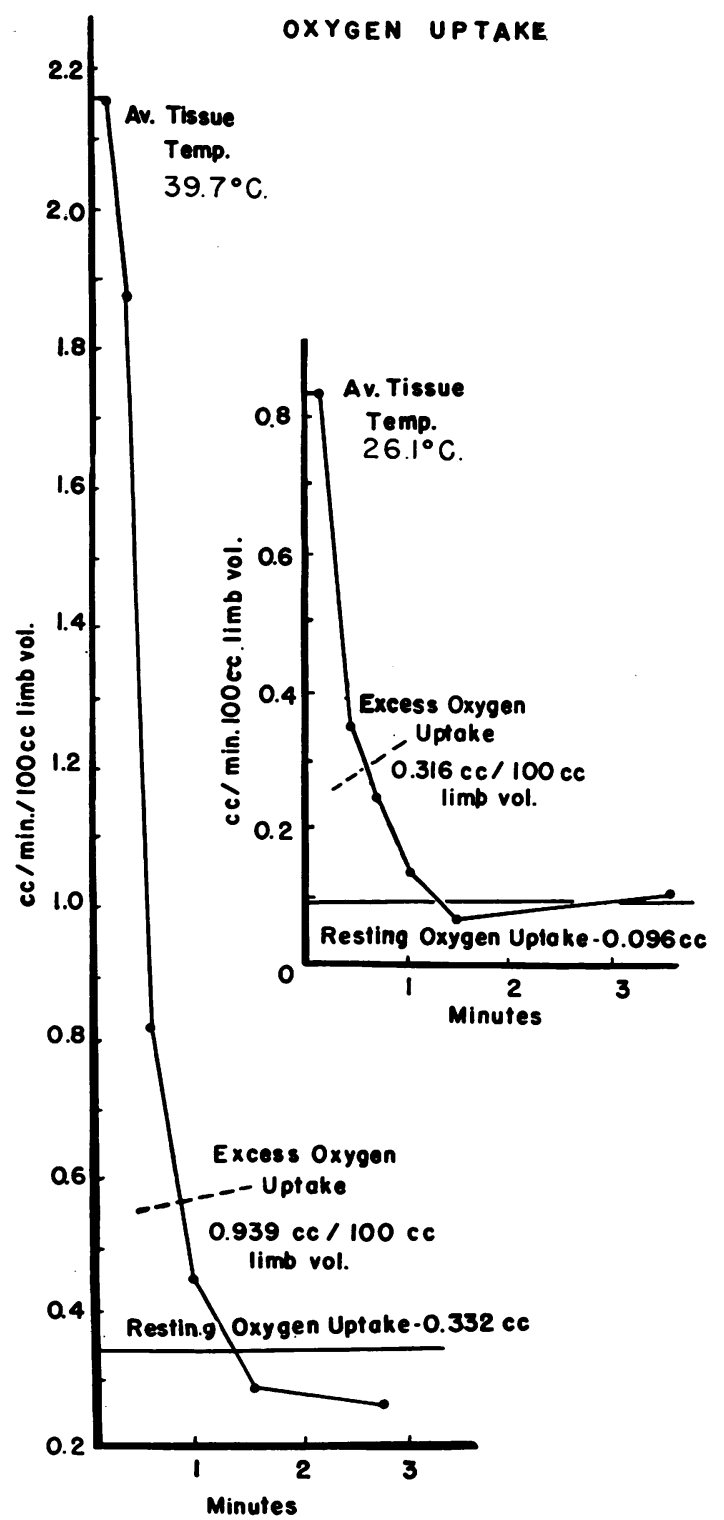

Fig. 3. Graphs of Oxygen Uptake Obtained During Reactive Hyperemia on Subject J. S.

Lower curve $=$ bath temperature of $45^{\circ} \mathrm{C}$. Upper curve $=$ bath temperature of $17^{\circ} \mathrm{C}$. Graphs are based on blood flow and oxygen arteriovenous differences as depicted in Figure 2.

flow and oxygen uptake graphs, the area under the curve and above the baseline was then determined by means of a planimeter and expressed in proper units by multiplying the result by an appropriate factor (Figures 2 to 5 ). The product was considered to represent the response produced solely by the period of arterial occlusion, since it 
did not include the changes which would ordinarily have taken place under resting conditions.

\section{Systemic alterations}

As in the previous study (4), exposure of the forearm to extremes of temperature did not cause any significant or consistent systemic reactions. At a bath temperature of $45^{\circ} \mathrm{C}$. some of the subjects experienced a sensation of warmth over the rest of the body and generalized sweating due to reflex vasodilatation. However, at a bath temperature of $17^{\circ} \mathrm{C}$. no systemic symptoms were experienced. With the forearm exposed to room air and subsequently to water at $45^{\circ} \mathrm{C}$., the rectal temperature was an average of $38.1^{\circ} \mathrm{C}$., while at a bath temperature of $17^{\circ}$ it was an average of $37.8^{\circ} \mathrm{C}$. Resting blood pressure and pulse rate showed no consistent changes at the two bath temperatures; nor did the application of an arterial occlusion pressure produce any significant alterations.

\section{Results obtained under resting conditions}

The data on blood flow, venous blood and tissue temperatures collected under resting conditions

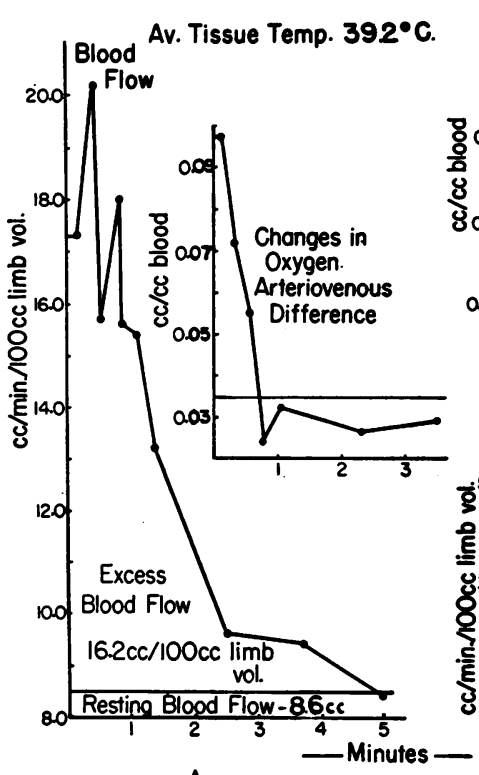

A
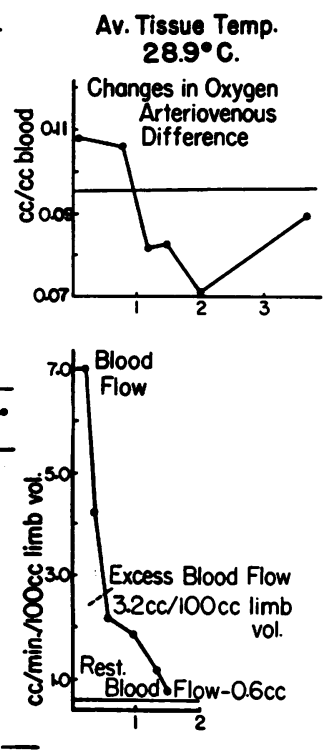

B
Fig. 4. Graphs of Blood Flow and Oxygen Arteriovenous Differences Obtained During Reactive HyPEREMIA on SubJect H. M.

$\mathrm{A}=$ bath temperature of $45^{\circ} \mathrm{C} . \quad \mathrm{B}=$ bath temperature of $17^{\circ} \mathrm{C}$.

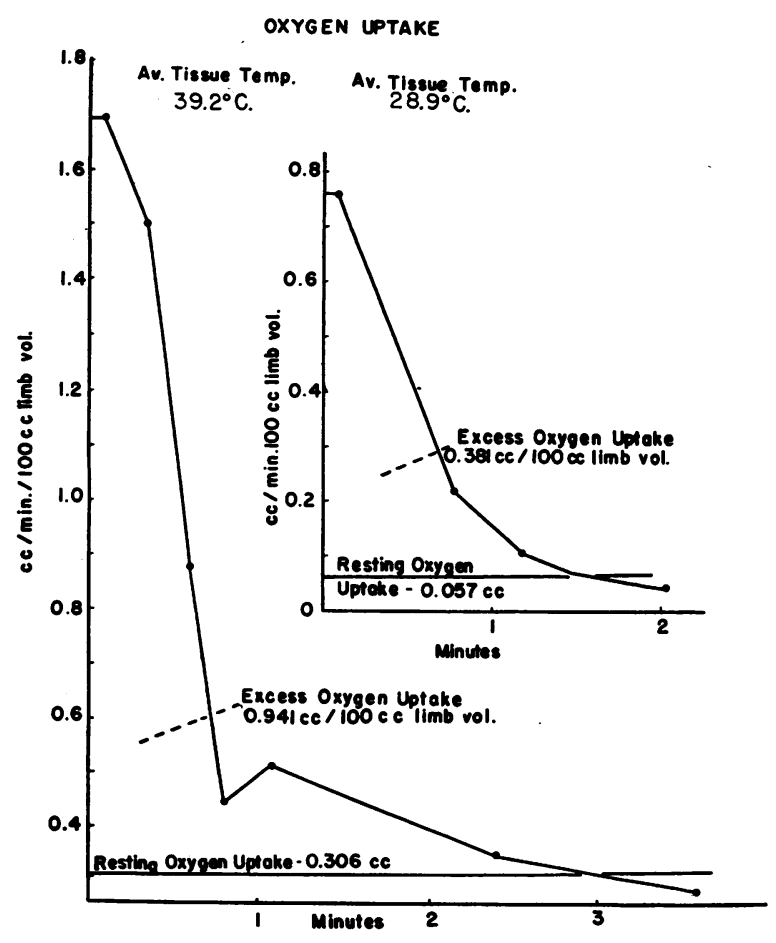

Fig. 5. Graphs of Oxygen Uptake Obtained During Reactive Hyperemia on Subject H. M.

Lower curve $=$ bath temperature of $45^{\circ} \mathrm{C}$. Upper curve $=$ bath temperature of $17^{\circ} \mathrm{C}$. Graphs are based on blood flow and oxygen arteriovenous differences as depicted in Figure 4.

are included in Table I. It will be noted that the average values for these readings at the two bath temperatures, as well as the calculations of oxygen uptake, were for the most part the same as those reported in a previous paper (4). The average temperature readings obtained in room air were: skin, $35.4^{\circ} \mathrm{C}$.; subcutaneous tissue, $35.3^{\circ}$; and muscle, $36.2^{\circ}$. The average tissue temperature under these circumstances was $36.0^{\circ}$.

\section{Blood flow responses during reactive hyperemia}

The blood flow curves obtained at the two bath temperatures after removal of the arterial occlusion pressure were similar in general contour (Figures 2 and 4). Under both experimental conditions the peak of the response occurred soon after the onset of reactive hyperemia, although being noted a little earlier at the lower bath temperature (an average of 9 seconds, as compared with 19 seconds for the higher bath temperature). Thereafter the curve fell either gradually or 
TABLE I

Effect of different bath temperatures on oxygen uptake of the forearm during reactive hyperemia

\begin{tabular}{|c|c|c|c|c|c|c|c|c|c|c|c|c|c|c|}
\hline \multirow[b]{3}{*}{ Subject } & \multirow[b]{3}{*}{$\begin{array}{c}\mathrm{O}_{2} \\
\text { capacity } \\
\text { cc. } / 100 \text { cc. } \\
\text { blood }\end{array}$} & \multirow[b]{3}{*}{$\begin{array}{l}\text { Calcu- } \\
\text { lated } \\
\text { art. O2 } \\
\text { cc. } 1100 c c . \\
\text { blood }\end{array}$} & \multicolumn{12}{|c|}{ Bath temperature $-45^{\circ} \mathrm{C}$. } \\
\hline & & & \multirow[b]{2}{*}{$\begin{array}{c}\text { Resting } \\
\text { venous } \\
\mathrm{O}_{2} \\
\text { cc. } 1100 c c . \\
\text { blood }\end{array}$} & \multirow[b]{2}{*}{$\begin{array}{l}\text { Resting } \\
\mathrm{O}_{2} \mathrm{~A} . \mathrm{V} . \\
\text { diff. } \\
c c . / c c . \\
\text { blood }\end{array}$} & \multirow[b]{2}{*}{$\begin{array}{c}\text { Resting } \\
\text { blood } \\
\text { flow } \\
\text { cc./min./ } \\
100 \text { cc. } \\
\text { limb vol. }\end{array}$} & \multirow[b]{2}{*}{$\begin{array}{c}\text { Resting } \\
\text { O2 uptake } \\
\text { cc./min./ } \\
\text { loo cc. } \\
\text { limb vol. }\end{array}$} & \multirow{2}{*}{$\begin{array}{c}\text { Excess } \\
\text { Oz uptake } \\
\text { during } \\
\text { reactive } \\
\text { hyper- } \\
\text { emia } \\
\text { cc./100 cc. } \\
\text { limb vol. }\end{array}$} & \multirow{2}{*}{$\begin{array}{c}\text { Pre- } \\
\text { dicted } \\
\text { excess } \mathrm{O}_{2} \\
\text { uptake } \\
\text { during } \\
\text { reactive } \\
\text { hyperemia } \\
\text { cc./100 cc. } \\
\text { limb vol. }\end{array}$} & \multirow{2}{*}{$\begin{array}{l}\text { Excess } \\
\text { blood } \\
\text { flow } \\
\text { during } \\
\text { reactive } \\
\text { hyper- } \\
\text { emia } \\
\text { cc./100 cc. } \\
\text { limb vol. }\end{array}$} & \multicolumn{5}{|c|}{ Temp. ${ }^{\circ} \mathrm{C}}$. \\
\hline & & & & & & & & & & Skin & $\begin{array}{l}\text { Sub- } \\
\text { cuta- } \\
\text { neous } \\
\text { tissue }\end{array}$ & Muscle & $\begin{array}{c}\text { Aver- } \\
\text { age } \\
\text { tissue }\end{array}$ & Rectal \\
\hline M. M. & 17.38 & 17.03 & 12.99 & 0.0404 & 8.4 & 0.343 & 0.871 & 1.715 & 7.8 & 40.8 & 40.2 & 39.2 & 39.4 & 38.3 \\
\hline H. R.* & 20.53 & 20.12 & 16.15 & 0.0397 & 7.9 & 0.314 & 0.522 & 1.570 & 5.9 & 42.0 & 41.1 & 38.6 & 39.1 & 38.1 \\
\hline B. M. & 19.63 & 19.24 & 16.45 & 0.0279 & 9.6 & 0.268 & 0.660 & 1.340 & 6.0 & 41.3 & 40.8 & 39.5 & 39.8 & 38.4 \\
\hline A. L. & 20.49 & 20.08 & 14.20 & 0.0588 & 8.8 & 0.517 & 0.862 & 2.585 & 15.6 & 41.8 & 39.6 & 38.7 & 39.0 & 38.3 \\
\hline S. $\mathbf{M}$. & 21.16 & 20.74 & 16.38 & 0.0436 & 10.0 & 0.436 & 0.991 & 2.180 & 10.0 & 41.3 & 38.7 & 38.0 & 38.3 & 37.7 \\
\hline E. G. & 20.31 & 19.90 & 13.94 & 0.0596 & 8.0 & 0.477 & 0.731 & 2.385 & 8.2 & 43.9 & 42.9 & 39.7 & 40.3 & 38.2 \\
\hline G. B. & 21.98 & 21.54 & 17.32 & 0.0422 & 9.2 & 0.388 & 1.820 & 1.940 & 14.5 & 42.6 & 41.4 & 38.5 & 39.1 & 38.3 \\
\hline H. M. & 20.99 & 20.57 & 17.01 & 0.0356 & 8.6 & 0.306 & 0.941 & 1.530 & 16.2 & 41.5 & 40.7 & 38.8 & 39.2 & 38.5 \\
\hline A. $\mathbf{R}$. & 18.85 & 18.47 & 14.18 & 0.0429 & 4.8 & 0.206 & 1.226 & 1.030 & 12.7 & 42.5 & 41.8 & 41.2 & 41.4 & 38.6 \\
\hline J. B.* & 17.86 & 17.50 & 11.22 & 0.0628 & 8.6 & 0.540 & 0.460 & 2.700 & 9.1 & 43.0 & 42.1 & 39.8 & 40.3 & 38.4 \\
\hline A. $\mathrm{K}$. & 20.18 & 19.78 & 12.39 & 0.0739 & 9.6 & 0.709 & 0.283 & 3.545 & 11.9 & 43.0 & 42.5 & 39.9 & 40.4 & 38.7 \\
\hline J. S. & 20.73 & 20.31 & 15.20 & 0.0511 & 6.5 & 0.332 & 0.939 & 1.660 & 11.5 & 42.9 & 41.5 & 39.2 & 39.7 & 38.2 \\
\hline E. W. & 17.29 & 16.94 & 14.23 & 0.0271 & 8.2 & 0.222 & 0.773 & 1.110 & 7.6 & 42.8 & 41.0 & 38.1 & 38.8 & 37.6 \\
\hline M. S. & 19.32 & 18.93 & 14.82 & 0.0411 & 10.4 & 0.427 & 0.821 & 2.135 & 9.6 & 42.0 & 40.5 & 38.8 & 39.2 & 37.9 \\
\hline E. P. & 20.42 & 20.01 & 15.10 & 0.0491 & 8.5 & 0.417 & 0.532 & 2.085 & 10.7 & 41.7 & 42.2 & 39.1 & 39.6 & 38.5 \\
\hline A. $\mathbf{M}$. & 18.00 & 17.64 & 11.94 & 0.0576 & 11.7 & 0.667 & 0.613 & 3.335 & 7.5 & 41.4 & 39.8 & 38.2 & 38.6 & 37.4 \\
\hline H. H.* & 20.27 & 19.86 & 15.76 & 0.0410 & 8.6 & 0.353 & 0.968 & 1.765 & 13.4 & 41.3 & 40.4 & 37.9 & 38.4 & 37.4 \\
\hline M. R.* & 21.19 & 20.77 & 16.19 & 0.0458 & 8.2 & 0.376 & 0.733 & 1.880 & 13.3 & 41.8 & 40.9 & 39.1 & 39.5 & 38.0 \\
\hline D. A. & 19.86 & 19.46 & 15.96 & 0.0350 & 7.0 & 0.245 & 0.803 & 1.225 & 5.0 & 41.4 & 41.6 & 38.5 & 39.0 & 38.0 \\
\hline C. M. & 16.34 & 16.01 & 9.55 & 0.0645 & 11.1 & 0.716 & 0.397 & 3.580 & 16.7 & 43.2 & 41.6 & 38.2 & 38.9 & 38.8 \\
\hline W. B. & 17.34 & 16.99 & 12.75 & 0.0424 & 9.2 & 0.390 & 0.507 & 1.950 & 6.5 & 40.6 & 41.4 & 38.7 & 39.1 & 38.0 \\
\hline D. B. & 23.06 & 22.60 & 17.01 & 0.0569 & 6.1 & 0.347 & 0.997 & 1.735 & 3.7 & 42.5 & 42.3 & 37.8 & 38.6 & 37.6 \\
\hline M. E. & 17.26 & 16.91 & 14.74 & 0.0217 & 13.8 & 0.299 & 1.042 & 1.495 & 13.7 & 42.3 & 40.5 & 39.3 & 39.7 & 38.4 \\
\hline \multirow{3}{*}{$\begin{array}{l}\text { Mean } \\
\text { Standard } \\
\text { error }\end{array}$} & 19.58 & 19.19 & 14.59 & 0.0461 & 8.8 & 0.404 & 0.804 & 2.021 & 10.3 & 42.1 & 41.1 & 38.9 & 39.3 & 38.1 \\
\hline & & & & \pm 0.0027 & \pm 0.4 & \pm 0.030 & \pm 0.067 & & & & & & & \\
\hline & & & \multicolumn{12}{|c|}{ Bath temperature $-17^{\circ} \mathrm{C}$. } \\
\hline M. M. & 17.38 & 17.03 & 9.48 & 0.0754 & 0.8 & 0.060 & 0.259 & 0.300 & 2.6 & 20.2 & 20.6 & 26.3 & 25.3 & 38.3 \\
\hline H. R.* & 20.53 & 20.12 & 13.26 & 0.0686 & 1.0 & 0.069 & 0.281 & 0.345 & 4.5 & 20.2 & 20.4 & 31.0 & 29.1 & 38.1 \\
\hline B. $\mathbf{M}$. & 19.63 & 19.24 & 13.73 & 0.0551 & 1.5 & 0.083 & 0.648 & 0.415 & 8.2 & 19.1 & 21.5 & 28.2 & 26.8 & 38.2 \\
\hline A. L. & 20.49 & 20.08 & 9.24 & 0.1084 & 0.8 & 0.087 & 0.241 & 0.435 & 1.8 & 19.6 & 21.4 & 27.3 & 26.1 & 38.1 \\
\hline S. M. & 21.16 & 20.74 & 12.35 & 0.0838 & 0.9 & 0.075 & 0.410 & 0.375 & 3.2 & 17.3 & 21.3 & 25.3 & 24.2 & 37.1 \\
\hline E. G. & 20.31 & 19.90 & 9.79 & 0.1011 & 0.7 & 0.071 & 0.422 & 0.355 & 2.9 & 18.3 & 18.6 & 25.8 & 24.5 & 38.0 \\
\hline G. B. & 21.98 & 21.54 & 19.22 & 0.0232 & 2.3 & 0.053 & 0.825 & 0.265 & 12.7 & 20.5 & 21.6 & 32.0 & 30.1 & 36.8 \\
\hline H. M. & 20.99 & 20.57 & 11.07 & 0.0950 & 0.6 & 0.057 & 0.381 & 0.285 & 3.2 & 18.7 & 26.9 & 30.2 & 28.9 & 38.4 \\
\hline A. $\mathbf{R}$. & 18.85 & 18.47 & 8.45 & 0.1002 & 0.7 & 0.070 & 0.481 & 0.350 & 5.1 & 19.7 & 20.1 & 28.8 & 27.2 & 37.7 \\
\hline J. B.* & 17.86 & 17.50 & 9.36 & 0.0814 & 1.4 & 0.114 & 0.644 & 0.570 & 6.3 & 18.8 & 19.9 & 28.1 & 26.6 & 38.1 \\
\hline A. $\mathrm{K}$. & 20.18 & 19.78 & 12.05 & 0.0773 & 1.2 & 0.093 & 0.304 & 0.465 & 4.5 & 19.4 & 19.8 & 26.4 & 25.2 & 38.4 \\
\hline J. S. & 20.73 & 20.31 & 14.18 & 0.0601 & 1.6 & 0.096 & 0.316 & 0.480 & 2.7 & 18.7 & 20.0 & 27.5 & 26.1 & 38.0 \\
\hline E. W. & 17.29 & 16.94 & 13.83 & 0.0311 & 0.9 & 0.028 & 0.301 & 0.140 & 2.6 & 18.0 & 20.8 & 25.7 & 24.6 & 37.6 \\
\hline M. S. & 19.32 & 18.93 & 9.07 & 0.0985 & 0.6 & 0.059 & 0.341 & 0.295 & 2.6 & 18.9 & 20.2 & 25.7 & 24.6 & 37.7 \\
\hline E. P. & 20.42 & 20.01 & 10.75 & 0.0921 & 0.5 & 0.046 & 0.222 & 0.230 & 2.1 & 17.1 & 18.6 & 26.4 & 24.9 & 38.2 \\
\hline A. M. & 18.00 & 17.64 & 8.97 & 0.0867 & 0.8 & 0.069 & 0.480 & 0.345 & 3.6 & 19.6 & 21.2 & 27.5 & 26.3 & 36.8 \\
\hline H. H.* & 20.27 & 19.86 & 14.15 & 0.0571 & 0.7 & 0.040 & 0.502 & 0.200 & 4.6 & 17.1 & 18.8 & 28.1 & 26.3 & 37.0 \\
\hline M. R.* & 21.19 & 20.77 & 14.15 & 0.0662 & 1.1 & 0.073 & 0.339 & 0.365 & 3.1 & 18.6 & 20.8 & 26.4 & 25.2 & 38.0 \\
\hline D. A. & 19.86 & 19.46 & 10.43 & 0.0903 & 0.7 & 0.063 & 0.495 & 0.315 & 5.1 & 20.0 & 19.3 & 29.8 & 28.0 & 37.8 \\
\hline C. M. & 16.34 & 16.01 & 11.09 & 0.0492 & 1.2 & 0.059 & 0.385 & 0.295 & 6.0 & 19.3 & 22.0 & 30.7 & 28.9 & 38.4 \\
\hline W. B. & 17.34 & 16.99 & 9.61 & 0.0738 & 0.9 & 0.066 & 0.247 & 0.330 & 2.3 & 21.8 & 20.7 & 30.3 & 28.7 & 36.6 \\
\hline D. B. & 23.06 & 22.60 & 10.18 & 0.1242 & 0.7 & 0.087 & 0.611 & 0.435 & 4.0 & 18.5 & 19.6 & 32.9 & 30.5 & 37.3 \\
\hline M. E. & 17.26 & 16.91 & 11.02 & 0.0589 & 1.4 & 0.082 & 0.286 & 0.410 & 5.3 & 18.2 & 20.7 & 30.5 & 28.6 & 38.1 \\
\hline $\begin{array}{c}\text { Mean } \\
\text { Standard }\end{array}$ & 19.58 & 19.19 & 11.54 & 0.0764 & 1.0 & 0.070 & 0.410 & 0.348 & 4.3 & 19.0 & 20.6 & 28.3 & 26.8 & 37.8 \\
\hline error & & & & \pm 0.0050 & \pm 0.1 & \pm 0.004 & \pm 0.029 & & & & & & & \\
\hline
\end{tabular}

* Average of two experiments. 
abruptly until the resting blood flow baseline was reached or crossed. This took place an average of 211 and 153 seconds after re-establishment of the circulation, for the high and low bath temperatures, respectively.

In every instance the maximum height the blood flow curve attained was much greater at a bath temperature of $45^{\circ} \mathrm{C}$. than at $17^{\circ}$ [an average of $18.4 \mathrm{cc}$. per minute per $100 \mathrm{cc}$. limb volume, as compared with $8.0 \mathrm{cc}$. (Figures 2 and 4 )]. However, when the actual maximum increase in excess of the resting level was calculated, this type of relationship was not as constant, being found in 20 experiments, while in the remaining 7 the figure was greater at the low bath temperature. Nevertheless, the average maximum rise in excess of the resting level for the group as a whole was still larger at the high bath temperature (an average of $9.8 \mathrm{cc}$. per minute per $100 \mathrm{cc}$. limb volume, as compared with $7.0 \mathrm{cc}$.).

The increase in blood flow in excess of the resting level during the period of reactive hyperemia was greater at the high bath temperature in all instances but four, while in the latter the reverse was true. For the group as a whole, the average excess blood flow at a bath temperature of $45^{\circ} \mathrm{C}$. was $10.3 \mathrm{cc}$. per $100 \mathrm{cc}$. limb volume, as compared with $4.3 \mathrm{cc}$. at a bath temperature of $17^{\circ}$ (Table I). Statistical analysis of the data revealed that this difference was very highly significant, with the probability that it rose simply by chance variation being less than 0.1 per cent $(p<0.001)(8)$.

\section{Changes in oxygen arteriovenous difference during reactive hyperemia}

The alterations in this figure following release of the arterial occlusion pressure showed no consistent pattern, as contrasted with the fairly uniform type of change observed in the blood flow response. At the high bath temperature in all instances but one the initial reading, obtained within four to six seconds after re-establishment of the circulation, demonstrated an increase in the oxygen arteriovenous difference that was greater than the subsequent determinations (Figures 2 and 4 ); in the one exception the first point was located below the baseline and then there was a rise above it. At the low bath temperature, in 21 cases the initial reading showed the greatest increase in oxy- gen arteriovenous difference (Figure 2); in 3 the second reading was the highest; while in 3 all the points fell on either side of the baseline. A considerable range in the magnitude of the initial peak reading was observed at the two bath temperatures. In 19 cases the height of the rise was greater at the high than at the low bath temperature; in 3 , the reverse was true; and in 5 , the figures were approximately the same under the two different environmental conditions.

In most instances at both the high and low bath temperature there was a rapid drop of the curve from the peak reading so that the baseline was reached within the first minute of the period of reactive hyperemia. At the high bath temperature, in 16 instances this level was not crossed, while in the remaining 11 the curve fell below it, remaining there for from one to three minutes (Figures 2 and 4 ). At the low bath temperature there was a drop below the baseline in 21 experiments (Figures 2 and 4 ), while in the remaining 6 all the readings remained above the baseline. Of the cases already described, in four instances at the high bath temperature and in six at the low bath temperature, alterations in oxygen arteriovenous difference showed little tendency to vary from the baseline.

\section{Changes in oxygen uptake during reactive hy- peremia}

As in the case of blood flow curves, the oxygen uptake graphs obtained at the two bath temperatures after release of the arterial occlusion pressure demonstrated certain similarities. Under both experimental conditions the peak of the response was noted within 3 to 15 seconds after reestablishment of the circulation, and in most instances this was followed by either a gradual or abrupt drop in the direction of the baseline (Figures 3 and 5). In four cases at the high bath temperature and in two at the low, a secondary and minor peak was observed 10 to 15 seconds after the initial and major rise. At the high bath temperature, in eight instances the curve fell below the baseline and remained there for from one to four minutes until it began to ascend again. This type of change was present only twice in the case of the low bath temperature.

Comparison of the oxygen uptake curves re- 
vealed that in every instance the peak was much higher at a bath temperature of $45^{\circ} \mathrm{C}$. than at $17^{\circ}$ (an average of 1.745 , cc. per minute per 100 cc. limb volume, as compared with $0.838 \mathrm{cc}$.). When the maximum increase in excess of the resting level was calculated, the above relationship was now observed in 22 cases, while in 5 the reading was greater at the lower bath temperature. The average rise above the baseline was $1.340 \mathrm{cc}$. per minute per $100 \mathrm{cc}$. limb volume at the high bath temperature and $0.769 \mathrm{cc}$. at the low bath temperature. The average period of time during which the oxygen uptake was still elevated above the resting level was longer at the high than the low bath temperature (187 as compared with 147 seconds).

The average excess oxygen uptake during reactive hyperemia at the high bath temperature was $0.804 \mathrm{cc}$. per $100 \mathrm{cc}$. of limb volume, as compared with $0.410 \mathrm{cc}$. at the low bath temperature (Table I). The data were analyzed statistically and it was found that this difference was very highly significant, with the probability that it rose simply by chance variation being less than 0.1 per cent $(\mathrm{p}<0.001)$ (8). In only one instance (J. B.) was the excess oxygen uptake during reactive hyperemia higher at $17^{\circ}$ than at $45^{\circ}$.

Comparison of actual oxygen uptake during reactive hyperemia with predicted oxygen debt for period of arterial occlusion

Examination of Table I reveals that at a bath temperature of $45^{\circ} \mathrm{C}$. the mean excess oxygen uptake observed during reactive hyperemia was much less than the mean predicted oxygen debt incurred in the previous period of arterial occlusion (an average of $0.804 \mathrm{cc}$. per $100 \mathrm{cc}$. limb volume, as compared with $2.021 \mathrm{cc}$.). That this difference was significant was substantiated by a statistical analysis of the data $(p<0.001)$.

At a bath temperature of $17^{\circ} \mathrm{C}$., however, the mean excess oxygen was $0.410 \mathrm{cc}$. per $100 \mathrm{cc}$. of limb volume, as compared with a predicted value of 0.348 cc. A statistical analysis of these data revealed no significant difference between the two sets of figures $(p>0.1)$.

\section{DISCUSSION}

The present study supports the view, previously expressed (4), that an experimentally produced rise in tissue temperature of the forearm elicits an increase in resting oxygen uptake, while a fall results in a decrease in this figure (Table I). The results further demonstrate that this type of relationship also exists for the magnitude of the oxygen debt developed in a period of arterial occlusion and subsequently repaid during reactive hyperemia. Since the differences at the two bath temperatures were not associated with any consistent systemic reactions, it is probable that they were in great part due to alterations in local mechanisms brought about by the changes in tissue temperature.

At both tissue temperatures the oxygen debt incurred by a five minute period of arterial occlusion appeared to be repaid primarily through an increased blood flow, while the mechanism of greater extraction of oxygen from each cc. of blood passing through the tissues played a role only in the first minute or less of the period of reactive hyperemia. In fact, in a number of instances at both tissue temperatures, there was very little change in oxygen arteriovenous difference, in contrast with the large augmentation of blood flow that invariably occurred with re-establishment of the circulation. These findings are in accord with those reported on the dog (9).

The larger excess oxygen uptake during reactive hyperemia at a tissue temperature of $39.3^{\circ} \mathrm{C}$., as compared with that at $26.8^{\circ}$, can be accounted for chiefly by more marked local circulatory changes occurring at the higher temperature. For example, under the latter circumstances, the height of the maximum peak of the blood flow curve in excess of the resting level was greater, the duration of the increase in blood flow was longer, and, most important, the excess quantity of blood entering the limb during reactive hyperemia was much larger than in the case of the lower tissue temperature.

There is a possibility, too, that at the higher tissue temperature the greater oxygen debt incurred in the period of arterial occlusion was satisfied in part by more effective removal of oxygen from each cc. of blood. In support of this view is the finding that in most of the experiments the initial increase in oxygen arteriovenous difference during reactive hyperemia was larger than at the low tissue temperature. Furthermore, there were fewer instances of a fall of the curve 
below the baseline, indicating a smaller than resting oxygen arteriovenous difference. ${ }^{5}$

Although the present study leaves no doubt as to the penetrating effect of topically applied heat and cold, it is necessary to point out that under resting conditions all the tissues of the forearm were not equally affected by these agents. Actually there was a gradient of vasodilatation or constriction, with the greatest change occurring in the cutaneous vessels and the least, in the arterial tree located in the deepest muscle bundles.

During reactive hyperemia the situation was altered. At a bath temperature of $45^{\circ} \mathrm{C}$. this state was associated primarily with further vasodilatation of arteries and arterioles in the deeper muscle layers, while the cutaneous vessels, already almost fully dilated by the heat, played little if any role in the response. The vascular contribution of the intervening tissues varied inversely with the distance from the surface of the limb.

The presence of such variations in vascular responses during reactive hyperemia constituted an objection to the use of blood from superficial tissues for the determination of representative figures of venous oxygen content, particularly at a high bath temperature. Under the latter circumstances the skin and subcutaneous tissue, having suffered from an oxygen debt during the previous period of arterial occlusion, would now remove large quantities of oxygen from the blood to satisfy this state. At the same time, however, the minimal vascular changes taking place in these tissues during reactive hyperemia would lead to a much greater depletion of oxygen from each cc. of blood than was occurring in the deep structures in which there was a simultaneous marked increase in circulation. It was because of this theoretical possibility that attempts were made to collect blood samples from veins which appeared to drain primarily deeper tissues. It was felt that oxygen arteriovenous differences thus obtained could with more basis be related to the blood flow changes taking place during reactive hyperemia, in order to arrive at an accurate figure for oxygen uptake.

It is of interest to speculate on the explanation

\footnotetext{
5 It is possible that at both tissue temperatures this type of response represented a situation in which the increase in blood flow at that moment was of greater magnitude than warranted for the satisfaction of the existing metabolic needs of the tissues.
}

for the significant difference observed at a bath temperature of $45^{\circ} \mathrm{C}$. between the actual excess oxygen uptake during reactive hyperemia and the predicted oxygen debt for the preceding period of arterial occlusion, and the similarity of these twe readings at a bath temperature of $17^{\circ}$. Several possibilities suggest themselves. First, at a bath temperature of $45^{\circ}$ most of the components of the vascular tree are markedly dilated and, as a result, are filled with a considerable volume of blood, in part, also due to the large arterial inflow. Hence, when the arterial occlusion pressure is suddenly applied, a large complement of blood is trapped in the arterial tree, the capillaries and the venules, some of which is then available as a source of tissue oxygen during the period of arterial occlusion. In other words, limited aerobic metabolism is possible under these circumstances. As a result, a smaller than anticipated oxygen debt would be incurred; this, in turn, being reflected in a decreased oxygen repayment during reactive hyperemia. Such a hypothesis is in part supported by the observation of Patterson (10) who reported that when the forearm was packed with blood preceding the application of an arterial occlusion pressure, there was a reduction in the magnitude of the blood flow repayment in the subsequent period of reactive hyperemia.

At a bath temperature of $17^{\circ} \mathrm{C}$. many of the superficial arterioles and capillaries are markedly constricted, and the total arterial inflow is low. As a consequence, the amount of blood that could be trapped in the forearm on the application of an arterial occlusion pressure, and thus considered as a potential source for aerobic metabolism, is small. Therefore, it would be expected that the magnitude of the oxygen debt developed in this period and subsequently repaid during reactive hyperemia would more closely approximate the predicted figure.

Another explanation that can be offered is that during a period of arterial occlusion the energy needs of the tissues are in part taken care of through anaerobic metabolism. On this basis, it is possible that at a bath temperature of $45^{\circ} \mathrm{C}$., on re-establishment of the circulation some of the lactic acid, among other substances formed under such circumstances, is washed out of the forearm by the very rapid inflow of blood and resynthesized in the presence of oxygen in distant organs, as for 
example, the liver. As a consequence, the local oxygen debt satisfied during reactive hyperemia would be smaller than the predicted figure by the amount repaid elsewhere.

At a bath temperature of $17^{\circ} \mathrm{C}$., however, the situation is somewhat different. Because the initial blood flow response during reactive hyperemia is not as great as that at the higher bath temperature (average peak reading of $8.0 \mathrm{cc}$. per minute per $100 \mathrm{cc}$. limb volume, as compared with 18.4 cc.), the washing-out process with regard to products of anaerobic activity would be much less effective. As a result, the importance of distant synthesis would tend to be minimized, and, consequently, the actual oxygen uptake of the tissues of the forearm during reactive hyperemia would be expected to approach the predicted oxygen debt for the period of arterial occlusion.

Another possibility is that since the resting oxygen uptake was calculated on the basis of blood which drained primarily deep structures, the reported readings at a bath temperature of $45^{\circ} \mathrm{C}$. were somewhat greater than a theoretical value which would have represented all the vascular tissues of the forearm (4). Under such circumstances, the predicted oxygen debt would also have to be considered larger than warranted. At the same time, the reading for oxygen repayment during reactive hyperemia was probably smaller than the true value because of the use of a resting oxygen uptake baseline in the derivation of this figure which was too high. However, it is doubtful whether such corrections, if they could have been made, would have materially altered the great difference observed between the predicted oxygen debt and the excess oxygen repayment.

Finally, certain technical difficulties may also have contributed to the findings. For example, if, instead of the 10 to 11 blood samples collected in the postocclusion period, it had been possible to obtain almost continuous measurement of venous oxygen content, the resulting curve of oxygen uptake would unquestionably have been depicted more exactly. ${ }^{\circ}$ Perhaps, under such circum-

\footnotetext{
${ }^{6}$ Early in the investigation the use of an oximeter and a cuvette was considered as a possible means of obtaining frequent readings, but it was found that with this method, accurate determinations were not possible in the case of venous blood samples collected early in reactive hyperemia because of their low oxygen content.
}

stances, the area under it would have been larger. On the other hand, at the low bath temperature, it is possible that the need for frequently repeated venous samples was not as great, in view of the less rapid and less marked responses during reactive hyperemia. On this basis, the observed curve of oxygen uptake could be considered to be a more accurate representation of the changes occurring in this period than in the case of the high bath temperature.

\section{SUMMARY AND CONCLUSIONS}

1) The effect of altering local external temperature on the oxygen uptake of the tissues of the forearm during reactive hyperemia was investigated in a series of 27 experiments on 23 healthy subjects.

2) Oxygen uptake was calculated for the periods before and after five minutes of arterial occlusion, on the basis of studies of blood flow, using the venous occlusion plethysmographic method, and of local oxygen arteriovenous difference.

3) With prolonged exposure of the forearm to a bath temperature of $45^{\circ} \mathrm{C}$., the mean tissue temperature rose from a control level of $36.0^{\circ} \mathrm{C}$. (obtained with the limb in contact with air), to $39.3^{\circ}$. After exposure to a bath temperature of $17^{\circ}$, the readings fell to an average of $26.8^{\circ}$.

4) During the period of reactive hyperemia at an average tissue temperature of $39.3^{\circ} \mathrm{C}$., the oxygen uptake in excess of the resting level was an average of $0.804 \mathrm{cc}$. per $100 \mathrm{cc}$. of limb volume, as compared with $0.410 \mathrm{cc}$. at a tissue temperature of $26.8^{\circ}$. This difference was found to be statistically significant.

5) At the high tissue temperature the average excess oxygen uptake during reactive hyperemia was found to be significantly less than the predicted oxygen debt for the previous period of arterial occlusion $(0.804 \mathrm{cc}$. per $100 \mathrm{cc}$. limb volume, as compared with $2.021 \mathrm{cc}$.), while at the low tissue temperature both figures were approximately the same $(0.410 \mathrm{cc}$. per $100 \mathrm{cc}$. limb volume, as compared with $0.348 \mathrm{cc}$.). An attempt was made to explain such findings.

6) Evidence was presented suggesting that at both bath temperatures the mechanism of repayment of an oxygen debt incurred in a period of arterial occlusion involved primarily an increase 
in local circulation, with the factor of greater removal of oxygen from the blood playing a secondary role.

It was concluded that experimentally depressing the local tissue temperature of the forearm from an artificially elevated level definitely decreases the oxygen debt incurred in a period of arterial occlusion and subsequently repaid during reactive hyperemia. The data were considered to support and strengthen the view, previously expressed, that increasing local temperature of tissues in vivo raises their oxygen uptake, while decreasing it has the opposite effect.

\section{ACKNOWLEDGMENT}

The authors wish to express their appreciation to Miss Yvonne Bell for technical assistance.

\section{REFERENCES}

1. Roy, C. S., and Brown, J. G. The blood-pressure and its variations in the arterioles, capillaries and smaller veins. J. Physiol. (Lond.) 1879, 2, 323.

2. Lewis, T., and Grant, $R$. Observations upon reactive hyperaemia in man. Heart 1925, 12, 73.
3. Abramson, D. I., Katzenstein, K. H., and Ferris, E. B., Jr. Observations on reactive hyperemia in various portions of the extremities. Amer. Heart J. 1941, 22, 329.

4. Abramson, D. I., Kahn, A., Tuck, S., Jr., Turman, G. A., Rejal, H., and Fleischer, C. J. Relationship between a range of tissue temperature and local oxygen uptake in the human forearm. I. Changes observed under resting conditions. J. clin. Invest. 1958, 37, 1031.

5. Moreira, M. F., Mottram, R. F., and Werner, A. Y. The effect of venous pressure on the oxygen content of venous blood in the deep forearm veins. J. Physiol. (Lond.) 1956, 133, 255.

6. Patterson, G. C., and Whelan, R. F. Reactive hyperaemia in the human forearm. Clin. Sci. 1955, 14, 197.

7. Mottram, R. F. The oxygen consumption of human skeletal muscle in vivo. J. Physiol. (Lond.) 1955, 128, 268.

8. Snedecor, G. W. Statistical Methods. Ames, Iowa State College Press, 1956, pp. 49 and 73.

9. Yonce, L. R. Oxygen consumption in skeletal muscle during reactive hyperemia. Fed. Proc. 1957, 16, 140.

10. Patterson, G. C. The role of intravascular pressure in the causation of reactive hyperaemia in the human forearm. Clin. Sci. 1956, 15, 17. 